\title{
CONSTITUTIONAL AND JUDICIAL LANGUAGE PROTECTION IN MULTILINGUAL STATES: A BRIEF OVERVIEW OF SOUTH AFRICA AND BELGIUM
}

\author{
Isabelle Bambust, ${ }^{*}$ Albert Kruger ${ }^{* *}$ and Thalia Kruger ${ }^{* * * * * * * *}$
}

\begin{abstract}
The purpose of this contribution is to provide a very modest comparison of judicial language protection in South Africa and in Belgium. First of all, the authors sketch briefly the historical context and the constitutional status of languages in both countries. It is difficult to argue that one always has a right to use his or her own language. However, the use of language has clear links to constitutional rights such as the right to a fair trial. The authors then consider the rules on the use of languages in court generally and in criminal proceedings particularly. Belgium has strict rules on the use of language, and these rules are based on strong principles of territoriality and monolingualism. South Africa, on the other hand, has 11 official languages, not linked to territories, but in practice these languages do not all enjoy the same protection. The pragmatic approach by the South African courts is indicated with reference to the case law.
\end{abstract}

Keywords: Language protection; comparison between South Africa and Belgium; historical approach; legal language protection; linguistic practice; language as human right; right to a fair trial; interpretation

\section{Introduction}

Language is intimately involved with culture, and it is widely accepted that no translation can give the full context and meaning of the original words. The drawbacks of translation are apparent in litigation, where a subtle turn of phrase can be differently interpreted by the judge.

One may wonder whether language problems would exist if everybody could speak all languages. At first sight, this seems to be a perfect solution to all problems relating to translation and the associated protection of rights. However, taking into account the phenomenon of language identity in its entire context (political ideologies, media, education, ...), language problems will undoubtedly remain, ironically even regardless of the language proficiency of those involved. Speaking different languages is not just a matter of skills, but also of preference. A person might be able to speak two languages equally well, yet might prefer the particular vocabulary or emotional value of a particular one of the two.

As it is impossible to create a world with only one language, people with different language skills and language inclinations must continue living together in the private sphere; in various churches, schools, leisure and other communities; in a commercial, administrative and judicial environment and so on. In each of these domains, there is a certain language visibility. Each activity takes place in a certain setting, which may also be tied to language. Individuals bring their own language to these activities and domains, resulting in a language interaction among the individual, the domain, the activity and the place.

Some of these interactions take place in domains that are regulated by law, most notably courts of law. Legal systems have to cope with the multitude of languages they

\footnotetext{
Researcher, University of Ghent.

** Judge of the High Court of South Africa, Professor Extraordinary in Roman Law, History of Law and Comparative Law at the University of the Free State.

Lecturer, University of Antwerp, Honorary Research Associate, University of Cape Town. This research was supported by the National Research Foundation of South Africa.

${ }^{* * * *}$ The authors wish to thank the Journal's editors and the peer reviewers for their useful comments and suggestions. We also thank Wilma Mostert for her assistance in formatting the text.
} 
are confronted with. And legal systems do cope in one way or another. The purpose of this article is to examine the coping mechanisms of two very different legal systems functioning in two very different social and cultural contexts, namely that of South Africa and of Belgium.

We first give a brief historical setting of the languages in South Africa and in Belgium. Then we examine various ways in which language can be a right. After this theoretical discussion, we turn to practice and discuss several language rules and their interpretation by the courts. The present article will only deal with internal civil and criminal language problems.

\section{Relevance of the Comparison}

In light of the above introduction, each comparison about language protection in different countries would seem relevant. Whether protection is national, European or global, it should have the same reasonable and ethical value, and it could encounter similar obstacles.

Moreover, in light of the principles of state and democracy, and the associated language protection, there is no crucial difference between the language policy problem in Europe and in Africa. ${ }^{1}$ A democratic state should have a language policy that enables citizens to participate in their daily affairs and protect their rights. ${ }^{2}$

Why then Belgium and South Africa? Both these countries are officially multilingual and, therefore, attractive for a micro-comparison. The two countries are very different on many scores. South Africa has a population of 50 million; ${ }^{3}$ Belgium of 11 million. ${ }^{4}$ Belgium is a rich developed country; ${ }^{5}$ South Africa is a developing country. ${ }^{6}$ Belgium has a complicated federal structure; South Africa's political structure is considerably more centralised and the provinces have limited powers. Belgium has three official languages $;{ }^{7}$ South Africa has $11 .^{8}$ The ways in which the two countries deal with language are very different, as will become clear in the discussion that follows.

\section{Brief Historical Context}

Both the South African and the Belgian language rules result from complicated historical processes. Bearing these particular contexts in mind is essential to understand current language rules. However, historical contexts may not prevail in the search for the best solutions for future language protection, as an overemphasis of history may unearth buried language frustrations.

\subsection{South Africa}

In the 80 or so years before the democratic changes of 1994, only English and Afrikaans were used as languages of record in the courts. South Africa's colonial past gave these two languages their dominant position. Dutch was used as an official language from

\footnotetext{
G. Hesseling, 'Taal en staat in Afrika - Een rechtsvergelijkende verkenning', 24 Van taal tot taal 143, at $152(1980)$. 
1652 when Jan van Riebeeck arrived in the Cape. ${ }^{9}$ The South Africa Act $1909,{ }^{10}$ which created the Union in South Africa in 1910, provided in Section 137 that both English and Dutch would be official languages of the Union. From 1925 'Dutch' in Section 137 of that Act was declared to include Afrikaans. ${ }^{11}$ Afrikaans displaced Dutch in practice in South Africa, and Act 8 of 1927 gave legal status to the use of Afrikaans as an official language. Following the termination of South Africa's membership of the Commonwealth, a new Constitution was adopted, creating the Republic of South Africa in the place of the Union of South Africa. ${ }^{12}$ From 1961, English and Afrikaans were the official languages of South Africa, to be treated on a footing of equality. ${ }^{13}$

In 1983, the tri-cameral parliament was created by the Republic of South Africa Constitution Act 110 of 1983. This new Constitution reiterated that English and Afrikaans were the official languages of South Africa. ${ }^{14}$ In respect of self-governing territories created by Act 110 of 1986, an indigenous African language could be used in those areas as an additional official language. ${ }^{15}$

With the passing of the Interim Constitution 200 of 1993 and the Final Constitution of 1996, South Africa became a Constitutional Democracy, where not parliament, but the Constitution is the superior authority. ${ }^{16}$ The Interim Constitution also ended the disproportionate advantage that Afrikaans and English had been enjoying and included nine other languages as official languages. This does not mean that the languages of all groups in South Africa have become official languages, but the most spoken languages have.

Afrikaans is the home language of $13.3 \%$ of the population (almost 6 million people). English is the first language of only 3.6 million. The biggest first language groups are the IsiZulu speakers (10.7 million, amounting to $23.8 \%$ of the population) and IsiXhosa speakers (7.9 million, amounting to $17.6 \%$ of the population). ${ }^{17}$ Most South Africans speak English (as a second language), which features prominently in official and business life. ${ }^{18}$ In 1822 , English was declared an official language in certain British colonial territories, which were later incorporated into the Union of South Africa. Today English is the country's lingua franca, and the primary language of government, business and commerce. ${ }^{19}$

\subsection{Belgium}

Theoretically, there is no official language indication in Belgium. The Dutch, French and German languages are not indicated in the Constitution as official languages. Because of the constitutional demarcation of language areas, Dutch, French and German obtained an official character. All three languages are used as court languages.

In order to see the Belgian language division in its true context, we have to go far back in history. Richard Cullen explains that 'the linguistic frontier between Romance

\footnotetext{
The settlement at the Cape was intended to be a half-way house for the sea route from Holland to the Dutch East India Islands. There was no intention to found a colony (H.R.M. Hahlo and E. Kahn, The Union of South Africa: The Development of its Laws and Constitution (1960), at 3).

${ }_{10}$ An Act of the British Parliament.

11 The Official Languages of the Union Act 8 of 1925, of which the Dutch text was signed by the GovernorGeneral.

12 Sec. 1 of Act 32 of 1961, the Republic of South Africa Constitution.

13 Sec. 107 of Act 32 of 1961.

14 Sec. 89(1)

15 On passing of the appropriate legislation - Sec. 89(3) of Act 110 of 1983.

16 Sec. 2 of the Constitution provides, 'This constitution is the supreme law of the republic; law or conduct inconsistent with it is invalid, and the obligations imposed by it be fulfilled'.

17 See South Africa's languages: <www.mediaclubsouthafrica.com/index.php?option=com_content\&vie $\mathrm{w}=$ article\&id=80:languages\&catid $=33:$ land_bg\&Itemid $=70>$ (27 August 2012).

18 Id.

19 Id. Tsotsi taal is amalgam of Afrikaans, English and a number of African languages, widely spoken in urban areas, mainly by males often associated with urban criminality. Fanagalo is a pidgin language that grew mainly on the gold mines essentially being a simplified version of isiZulu and isiXhosa incorporating elements from English, Afrikaans and Portuguese. About 70\% of the lexicon is from isiZulu (loc cit).
} 
and Germanic languages was fixed at the point of maximum (stable) Roman conquest. It remains at this point, essentially, today' ${ }^{20}$ Also, Luc Van Durme confirms that 'the roots of the early medieval language border are to be found in the boundary line of the late Roman Empire'. ${ }^{21}$ When the Romans dominated the current Belgian territory, the local language was the Celtic language. The occupants spoke Latin as lingua franca. Around the year 250, AD the Germanic Franks crossed the Rhine. Basically, the Frankish language developed into Dutch. In the South, the popular Latin had a stronger influence, and this grew into French. ${ }^{22}$

After the fall of the west Roman empire, Germanic languages were spoken in the northern part of the Frankish empire, while Roman languages dominated in the southern area. There is no consensus among historians on the origin of that linguistic border. However, that border would not be much different from the current Belgian language border. According to J. Clement, ${ }^{23}$ who refers to M. Gijsseling, the main reason could lie in the Roman influence of the church. However, to our minds, the direct influence of the Roman domination itself should not be underestimated.

In 1830, Belgium became independent from the Netherlands. One of the causes for the desire of the southern provinces to become independent was the increasing use of Dutch in the administration. The main official language in that new State was French. The everyday language in the north was Flemish, while Walloon dialects were spoken in the south. In the north, the supremacy of the French language soon started to cause resentment. The Flemish movement promoted the establishment of Dutch as an official language. In the 19th and 20th centuries, several language laws in judicial and administrative matters were passed.

After the First World War, the Treaty of Versailles of 1920 transferred the German cantons of Eupen, Malmedy and Sankt Vith on a provisional basis to Belgium. In 1925, this region was included permanently in the Belgian State.

The principle of territoriality was introduced in Belgium in 1921 and confirmed in 1930 and 1962. This means that language regions were outlined: the language for each region was the language spoken by the majority of the population. Every 10 years, a census was conducted. A municipality could only change its linguistic status according to the findings of the census. This resulted in a flexible principle of territoriality, with the possibility for minorities representing at least 30 percent of the local population to obtain services in their mother tongue. However, this system was not approved universally, and since 1962 each municipality belongs to only one language area. From then on, modifications of the linguistic regime are only possible after changing the law, which requires a majority of each language community.

Unlike South Africa, Belgium has no unique lingua franca. French, Dutch and German are used in the official life of their specific territories. ${ }^{24}$

\subsection{Comparison of Historical Contexts}

The historical contexts and legal systems of the States discussed here are totally different. In South Africa, indigenous languages came in contact with two other languages, brought by the Dutch seafarers and the English colonialists. These two languages have long stood in an advantageous position in the South African political system and court structure. It is only since 1994 that nine other languages have been attributed more attention at the national level.

In Belgium, the indigenous languages are Dutch and French. Those two languages grew together (and without external input) in a roman western law model. Dutch- and

20 R. Cullen, 'Adaptive Federalism in Belgium', 13 University of New South Wales Law Journal 346, at 348 (1990).

${ }_{21}$ L. Van Durme, 'Genesis and Evolution of the Romance-Germanic Language Border in Europe', 23 Journal of Multilingual and Multicultural Development 9, at 12 (2002).

${ }_{22}$ For a complete and detailed overview of the national language history from the early Middle Ages, see

J. Clement, Taalvrijheid, bestuurstaal en minderheidsrechten - Het Belgisch model (2003), at 926.

${ }_{23}$ Id., at 11 .

24 There are no reliable statistics of the languages spoken by the population in those language territories. 
French-speaking people belong to one (legal) culture (even if the contrary is sometimes stated in political disputes). German has been added as a language due to the addition of territory after the Wars. This language has received due attention in the political system and courts.

The main resemblance lies in the fact that there was (and still is) an important language confrontation in South Africa due to colonisation and in Belgium because of a natural language frontier that became a kind of language Iron Curtain.

\section{The Nature of Language Rights}

Although it is difficult to argue that the use of one's preferred language is in itself a human right, and we will not venture to do so; we will indicate the delicate and complex link between language rights and basic human rights.

\subsection{The Relevance of Official Languages}

When one thinks of language protection and of the use of language in a particular country, one might consider the place of official languages of particular importance. In multilingual states, the relation between the various official languages poses an interesting question and a challenge in the case of developing countries. We will consider this relation below. However, the relation between the use of official and non-official languages is not fundamentally different in a single-language and a multilingual state. Those aspects of the discussion below are transposable to almost any state.

Official languages are in the first place fixed by the constitution.

In the Founding Provisions ${ }^{25}$ of the South African Constitution, ${ }^{26}$ Section 6 deals with languages:

1) The official languages of the Republic are Sepedi, Sesotho, Setswana, siSwati, Tshivenda, Xitsonga, Afrikaans, English, isiNdebele, isiXhosa and isiZulu.

2) Recognising the historically diminished use and status of the indigenous languages of our people, the state must take practical and positive measures to elevate the status and advance the use of these languages.

a) The national government and provincial governments may use any particular official languages for the purposes of government, taking into account usage, practicality, expense, regional circumstances and the balance of the needs and preferences of the population as a whole or in the province concerned; but the national government and each provincial government must use at least two official languages.

b) Municipalities must take into account the language usage and preferences of their residents. ${ }^{27}$

The framers of the Constitution were of the view that the indigenous African languages had not received adequate recognition before 1994, and envisaged steps to advance those languages. As will appear below, in the law courts, the advancement of indigenous African languages was minuscule.

25 Chap. 1 of the Constitution 108 of 1996

26 Act 108 of 1996.

27 Subsection (4) deals with the duties of national and provincial governments to regulate and monitor the use of official languages, and subsection (5) deals with the establishment of a Pan South African Language Board, which was established by Act 59 of 1995. 
Currie points out that no immediate or practical consequences follow merely from the declaration of a language as an official language. ${ }^{28}$ The right is given content inter alia by use in a court of law. ${ }^{29}$

When interpreting this provision, the High Court held in $S$ v. Damoyi: $:^{30}$

It is quite evident that in terms of ss 6(2) and (4) of the Constitution both the national and the provincial governments have a constitutional duty to realise the objective envisaged in the aforementioned subsections, not only as regards the affairs of either the national and provincial governments but also as regards the conduct of court proceedings. Whether both the national and the provincial governments have the political will to do so remains to be seen.

A word should be said about Afrikaans. Although this language originated on African soil, it does not have historically diminished use and status as contemplated by Section 6(2) of the Constitution. On the contrary, it was rather advantaged by the pre-1994 government. ${ }^{31}$ Part of the reason why a universally acceptable language policy has not been implemented in the courts may be the position Afrikaans has obtained, which many do not want to relinquish. Judge J.C. Kriegler has said that at heart, the issue is ideological, not functional. He says the decision whether or not to jettison Afrikaans in the courts is inherently contentions and will have to be taken at a political level. ${ }^{32}$

When we turn to the Belgian Constitution, we find a division of the country into three communities: the Flemish Community, the French Community and the Germanspeaking Community. ${ }^{33}$

In 1970, four language areas were established: the Dutch language area, the French language area, the bilingual (French and Dutch) area of Brussels-Capital and the German language area. ${ }^{34}$ Each Belgian municipality belongs to one of these four language areas, and this language affiliation can only be changed by a special law supported by specific majorities. We, thus, see that the use of languages is strictly regulated in Belgium, and territorially determined, while in South Africa, the protection is guaranteed by the Constitution, but to a certain extent delegated to provinces and municipalities without strict conditions.

As becomes clear later in this article, the status as an official language has limited value. On the one hand, not all official languages are in practice equal in standing. On the other hand, interpretation in criminal proceedings is provided whether or not the language of the accused person is an official language.

\subsection{The Right/Freedom to Use Any Language}

The Belgian Constitution also enshrines the right to use any language. This right may be limited only by legislation and only for acts of public authority or for legal proceedings. ${ }^{35}$ These exceptions may be imposed by the federal authority and thus for the whole country. However, the French, Flemish and German-speaking ${ }^{36}$ Communities ${ }^{37}$ within

\footnotetext{
28 I. Currie, 'Official Languages and Language Rights', in S. Woolman, et al. (eds.), Constitutional Law of South Africa, Vol. IV, 2nd edn (loose-leaf) (2011, Revision Service 33), at 65-5.

29 Id., with reference to M.W. Wernner, 'The Politics of Equality Among European Linguistic Minorities', in R.P. Claude (ed.), Comparative Human Rights, at 184-213 (1976).

30 See 2004 (2) SA 564 (C), para 8.

31 Currie, above n. 28, para 65.5, last sentence.

32 These comments of Judge Kriegler are reflected in the report of the South African Heads of Court, discussed below. The emotional weight of current discussions about the place of Afrikaans can be seen in a poem by B. Breytenbach, Die beginsel van Stof (2011), at 12.

33 Sec. 2 of the Belgian Constitution, 1994. Sec. 3 establishes three regions, territorially determined. The regions have powers in matters such as the environment, and they will not be further discussed in this article.

34 This has been reiterated by the 1994 Constitution, Sec. 4.

35 Sec. 30 of the Belgian Constitution, 1994.

36 The German-speaking community intervenes only in education language matters.

37 It is not the regions, but the communities that issue decrees about languages.
} 
the limits of their territories, regulate three other aspects of language use, namely (1) in administrative matters, (2) in education institutions created, subsidised or acknowledged by the public authorities, and (3) in social relations between employers and employees, as well as in the acts and documents of enterprises made compulsory by the law and regulations. $^{38}$

J. Clement describes a teleological interpretation of the freedom of language. ${ }^{39} \mathrm{An}$ interference with the freedom will only be a violation if it does not fall in the scope of one of the specific language restrictions provided for by law. The author refers to the current interpretation of the freedom of language (in public matters), arguing in favour of a modern freedom supported by a duty for the State. According to this interpretation, the government must (only) ensure that the residents of a certain language area can conduct their legal proceedings in the language of that area.

Thus, in interpreting the freedom of language, the author is strongly influenced by the territorial character of language protection. Such interpretation makes the protection inflexible. German speakers in Belgium amount to only 70,000, but they remain protected because they live in a particular area. Larger language groups in Belgium that are legally not considered as language minorities (e.g. the dispersed Italian-speaking population) are not afforded the same protection.

It is interesting to note a provision that was included in South Africa's Interim Constitution: ${ }^{40}$

A party to litigation, an accused person and a witness may, during the proceedings of a court, use the South African language of his or her choice, and may require such proceedings of a court in which he or she is involved to be interpreted in a language understood by him or her. ${ }^{41}$

The rule is much stronger than the one in the Belgian Constitution, as it applied throughout South Africa without territorial limitations. However, the provision was not taken up in the Final Constitution of 1996. It would have been a very expensive measure for the State to ensure.

Currently in civil litigation in South Africa, the parties bear the costs of interpretation for any language other than English or Afrikaans. Currie ${ }^{42}$ expresses the view that a litigant or witness in civil proceedings, who wishes to address the court in any of the official languages, should be allowed to do so. However, in practice, all civil proceedings are conducted in either English or Afrikaans. This goes for pleadings and argument in court and the judgement. Thus, we note a discrepancy between the right to use any language and the practical and cost implications, especially in a developing country with too many languages to guarantee the right.

\subsection{Language and Culture}

Language and the ability to use a particular language may be an extension of the right to culture. The South African Constitution refers to these rights together in its Section 30. Language is so intricately linked to culture and even identity that it has been described as the external manifestation of a people's soul..$^{43}$ This aspect of language rights places an extra burden on interpreters, especially in court rooms, where they have to convey more than literal meaning, but also context. We will discuss the function of interpreters later.

\footnotetext{
$38 \quad$ Secs. 129 and 130 of the Constitution, 1994.

39 See J. Clement, 'De taalvrijheid in de Grondwet. Ontwaakt de schone slaapster?' in A. Alen and

S. Sottiaux (eds.), Taaleisen juridisch getoetst (2009), at 17-32.

40 Act 200 of 1993.

41 Sec. 107

42 Subsection 65.6, Vol. IV

43 J.M.T. Labuschagne, 'Taalregte in die Regsproses $R$ v Beaulac [1999] 134 CCC (3d) 481 (SCC)', 63 Tydskrif vir Hedendaagse Romeins-Hollandse Reg 517, at 520-521 (2000).
} 


\subsection{Language as a Communication Right}

Allowing litigating parties to use an official language in court does not always sufficiently protect their rights. ${ }^{44}$ Some South African cases indicate that the right to use a preferred language in court is a communication right. ${ }^{45}$ In $S$ v Pienaar ${ }^{46}$ where the accused was provided with a legal representative he could not understand, the court held that the accused's right to a fair trial had been infringed. The court referred to the Canadian jurisprudence, where the content of a language right is explained. ${ }^{47}$ It has been argued that the right to use any of the official languages in court is more than a communication right, it is a fundamental human right. To use only English and Afrikaans in court proceedings is unfortunate, unconstitutional and untenable. ${ }^{48}$ All 11 languages are equal, notionally at any rate. ${ }^{49}$ In 1988 , before the present constitutional dispensation came into effect in South Africa in 1994, Professor C.R.M. Dlamini ${ }^{50}$ published an article on the influence of race in the administration of justice in South Africa. ${ }^{51}$ Dlamini refers to the case of $S$ $\mathrm{v}$ Mроро ${ }^{52}$ where the trial court drew an adverse influence against a witness on the basis of an understanding of the indigenous language the witness spoke, and it turned out that the witness had in fact spoken a different language. Language rights as well as the right to a fair trial will be undermined by poor translation. ${ }^{53}$

The Constitution, furthermore, states that the need for the judiciary to reflect broadly the racial and gender composition of South Africa must be considered when judicial officers are appointed. ${ }^{54}$ People need to understand and be able to conduct proceedings in the language of their choice. ${ }^{55}$ In this sense, the Constitution uses language as a tool to transform society and to strive towards more equality.

\subsection{The Right to a Fair Trial and Language}

The right to a fair trial is enshrined in the South African Bill of Rights ${ }^{56}$ and in the European Convention on Human Rights (ECHR), which forms part of Belgian law. ${ }^{57}$ The South African Bill of Rights provides in Section 35(3)(k) for the right to a fair trial, which includes the right:

to be tried in a language that the accused person understands.

Moreover, everyone has the right to have any dispute that can be decided by the application of law decided in a fair public hearing before a court. ${ }^{58}$ The Constitution provides for

\footnotetext{
44 For an argument in favour of allowing the use of other langauges, see T. Sterk, De taal van het proces. Mag het ook een andere zijn? (2001).

45 H.J. Lubbe, 'The Right to Language Use in Court: A Language Right or a Communication Right?', APP International Conference 16-19 July 2008, <http://humanities.ufs.ac.za/content.aspx?uid=165>. $S$ v Matomela 1998 (3) BCLR 339 (Ck), S v Damoyi 2004 (2) SA 564 (C).

462000 (2) SACR 143 (NC).

47 See Lubbe, above n. 45, at 382-385.

48 Id., at 386, with reference to J.M. Hlope, 'Official Languages and the Courts', 117 South African Law Journal 4, at 690-696 (2000).

49 Hlope, above n. 48, at 694.

50 At the time attached to the University of Zululand.

51 C.R.M Dlamini, 'The Influence of Race on the Administration of Justice in South Africa', 4 South African Journal on Human Rights 37 (1988).

521978 (2) SA 424 (A).

53 N.C. Steytler, 'Implementing Language Rights in Court: The Role of the Court Interpreter', 9 South African Journal on Human Rights (1993), at 205.

54 Sec. 174(2) of the Constitution.

55 Memorandum by Judge President Ngoepe for the Transformation Sub-Committee of the National Monitoring Committee, dated 11 February 2011.

56 Secs. 34 and 35 of the South African Bill of Rights, which is Chap. 2 of the Constitution.

57 Art. 6(1) of the ECHR.

58 Sec. 34 of the South African Constitution, 1996.
} 
fairness in a civil trial ${ }^{59}$ and protects the right to a fair trial. ${ }^{60}$ The Constitution wants to create a situation where more and more of the official languages are used in court. ${ }^{61}$ The wording of Section 6(2) dealing with language rights is couched in peremptory terms: 'the state must take practical and positive measures'. ${ }^{62}$ Section $35(3)(\mathrm{k})$ of the South African Constitution gives limited protection. ${ }^{63}$ It cannot be used to limit existing rights. ${ }^{64}$

The ECHR specifically provides that an arrested person shall be informed, in a language which he understands, of the reasons for his arrest and of any charge against him, ${ }^{65}$ and that a person charged with a criminal offence shall be informed, in a language which he understands and in detail, of the nature and cause of the accusation against him and shall have free assistance of an interpreter if he cannot understand or speak the language used in court. ${ }^{66}$

The European Court of Human Rights has dealt with linguistic rights under different rights guaranteed by the Convention. The Court has pointed out that linguistic freedom as such is not one of the rights governed by the Convention. With the exception of the specific rights in criminal matters referred to above, the Convention does not explicitly guarantee the right to use a particular language in communications with public authorities or the right to receive information in a language of one's choice. In principle, States party to the Convention are free to regulate the use of their official language(s) ${ }^{67}$ However, the European Court of Human Rights has not yet had the opportunity to rule on the issue of language rights with specific reference to a fair civil trial. ${ }^{68}$

Anecessary condition for a fair trial is not merely access to justice, but also intellectual access to justice. ${ }^{69}$ In other words, when a person is summoned before a judge, he or she must be able to understand the claim. The question arises how the language protection must be given form as an element of a fair trial. Is translation always necessary? Does the recipient of a writ in a foreign language (which he or she does not understand) have the right to obtain the document in a comprehensible language? According to F. Matscher, it is first of all essential that the summoned person has effectively been informed of the procedure. It is also important that the transmission of documents somehow provides the addressee the opportunity to understand the contents of the message. A translation should not be necessary in every case. In other words, F. Matscher supports the view that the linguistic right, and the right to translation, in particular, is not an autonomous right but a right that is situated under the umbrella of a fair trial and the principle of equality. ${ }^{70}$

\footnotetext{
59 K. Malan, 'Oor die Hofnotuleringstaal in die lig van die Grondwet en na aanleiding van onlangse regspraak', 61 Tydskrif vir Hedendaagse Romeins-Hollandse Reg 696, at 702 (1998), with reference to Bernstein v. Bester 1996 (4) BCLR 449 (CC) 102-106 which dealt with Sec. 22 of the Interim Constitution, which was differently worded to Sec. 34 .

60 Id., at 702.

61 Id., at 704 .

62 In contradiction with Sec. 9(2) dealing with Equality, which states that steps 'may' be taken to address inequality. Id., at 704-705.

63 Malan, above n. 59, at 705.

64 Id., at 700-701.

65 Art. 5(2) ECHR

66 Art. 5(3)a and e.

${ }^{67}$ See 'Cultural Rights in the Case-law of the European Court of Human Rights', Council of Europe/ European Court of Human Rights, <www.echr.coe.int > (last visited Jan. 2011).

68 See 'Manuel pratique sur le fonctionnement de la Convention de La Haye du 15 novembre 1965 relative à la signification et la notification à l'étranger des actes judiciaires et extra-judiciaires en matière civile ou commerciale', (2006), at 88, nr. 227; 'La Cour européenne des Droits de l'Homme à Strasbourg n'a, à notre connaissance, pas encore eu à se prononcer sur l'exigence d'une notification dans la langue du destinataire dans le cadre d'une affaire civile ou commerciale'.

69 See N. Fricero, 'L'acte introductif d'instance et la transmission des actes au regard de la Convention européenne des droit de l'homme', Nouveaux droits dans un nouvel espace européen de justice : le droit processuel et le droit d'exécution (2002), at 47 and 49.

70 F. Matscher, 'Sprache der Auslandszustellung und Art. 6 EMRK', 4 IPRax 274 (1999). See also Ch. van Heukelen, 'Taalproblematiek bij de betekening aan een buitenlandse bestemmeling', in M. Pertegas, S. Brijs, \& L. Samyn (eds.), Betekenen en uitvoeren over de grenzen heen (2008), at 49-75.
} 
If the right to language (and by extension the right to translation) is not an independent right, the result might be that the addressee does not fully understand that important document introducing the proceedings, but that only his or her lawyer understands it. The addressee would, in fact, have to know the language of the place where he or she lives in order to maintain a firm grip on the proceedings. But is such fiction still tenable? E. Brems argues that existing jurisprudence of the European Court of Human Rights offers no guarantee that the principle of territoriality would remain immune to international control mechanisms concerning human rights. ${ }^{71}$

In light of the right to a fair trial and the case law of the European Court of Human Rights, the European Union adopted a Directive in 2010 on the right to interpretation and translation. ${ }^{72}$ It concerns criminal proceedings and proceedings for the execution of a European arrest warrant. ${ }^{73}$ It obliges European Union Member States to (1) provide suspected or accused persons who do not speak or understand the language of the criminal proceedings with interpretation during criminal proceedings before investigative and judicial authorities, including during police questioning, all court hearings and any necessary interim hearings, ${ }^{74}$ and (2) provide such persons with a written translation of all documents that are essential to ensure that they are able to exercise their right of defence and to ensure the fairness of the proceedings. ${ }^{75}$

According to L. Huybrechts, Belgian law, in general, complies with the ECHR's right to a fair trial and with the Directive. However, he states that a clear and smooth judicial control on the quality of the interpretation and the translation is still absent. ${ }^{76}$

Concluding this section, it is appropriate to refer to a case decided by the UN Human Rights Committee (HRC), responsible for interpreting and monitoring compliance with the International Covenant on Civil and Political Rights (which all EU Member States have joined). In the case of Diergaardt v Namibia, the applicants belonged to a minority group of European descent, which had formerly enjoyed political autonomy and now fell within the State of Namibia. The language used by this community was Afrikaans. The applicants complained that during court proceedings, they were obliged to use English rather than their mother tongue. The HRC found that there had been no violation of the right to a fair trial, since the applicants could not show that they were negatively affected by the use of English during court proceedings. This would suggest that the right to an interpreter during a trial does not extend to situations, where the language is simply not the mother tongue of the alleged victim. Rather, it must be the case that the victim is not sufficiently able to understand or communicate in that language. ${ }^{77}$

The question remains whether the right to language (including the associated right to translation or interpretation) is a right in itself, or whether it is one of the elements to the right to a fair trial. If it is such element, the right to language only exists to the extent that a litigating party or an accused person was due to the language barrier unable to exercise his or her right to a fair trial. In our opinion, these questions will increasingly be posed on both national and international courts.

\footnotetext{
71 E. Brems, 'Vlaamse taalvereisten getoetst aan internationale mensenrechtenverdragen', in A. Alen and S. Sottiaux (eds.), Taaleisen juridisch getoetst (2009), at 7.

72 Directive 2010/64/EU of the European Parliament and of the Council of 20 October 2010 on the right to interpretation and translation in criminal proceedings; OJ L 280, 26 October 2010, 1. Member States have until 27 October 2013 to comply with this Directive. See specifically Consideration 14.

73 Art. 1.1. of the Directive 2010/64.

74 Art. 2.1. of the Directive 2010/64.

75 Art. 3.1. of the Directive 2010/64.

76 L. Huybrechts, 'De Europese Richtlijn betreffende het recht op vertolking en vertaling in strafprocedures en de Belgische wet en rechtspraak', 1 Nullum Crimen 7 (2011).

77 See 'Handbook on European non-discrimination law', Council of Europe/European Court of Human Rights, 2011, <www.echr.coe.int>, at 115. The applicants also complained of a State policy to refuse to respond in Afrikaans to any written or oral communications from the applicants even though they had the ability to do so. The HRC found that the State's official policy of refusing to communicate in a language other than the official language (English) constituted a violation of the right to equality before the law on the basis of language. While the State may choose its official language, it must allow officials to respond in other languages where they are able to do so.
} 


\section{$5 \quad$ Legal Proceedings}

\subsection{Rules Determining the Language to be Used in Legal Proceedings}

As courts are part of the State mechanism, the languages determined for use in legal proceedings are in the first place official languages. Which of the official languages is used in a particular trial is regulated very differently in South Africa and in Belgium.

In South Africa, The Magistrates' Courts Act 32 of 1944, which deals with lower court civil and criminal matters, provides:

Either of the official languages may be used at any stage of the proceedings in any court and the evidence shall be recorded in the language so used. ${ }^{78}$

A provision similar to Section 6 of the Magistrates' Courts Act is contained in the Small Claims Court Act 61 of $1984 .{ }^{79}$ The two official languages referred to in these sections are English and Afrikaans (being the official languages at the time the section was enacted). If these provisions create constitutional duties, it can be argued that they also create constitutional rights ${ }^{80}$ However, in practice, pleadings are drawn up in the language of choice of the litigant, but only English and Afrikaans are used.

Using another language would cause practical difficulties and financial burdens, as pleadings would then have to be interpreted for the judge to understand, or, if the judge follows the language used, for purposes of the record. We, therefore, see that language rights in South Africa are not strictly regulated, which might result in less protection for litigants.

In Belgium, a strong territoriality principle reigns, while this is not the case in South Africa. Among a large number of Belgium's language laws, we find the important Act of 15 June 1935 regarding the languages used in judicial proceedings. ${ }^{81}$ This Act contains an unusual mixture of, on the one hand, a severe territoriality principle ${ }^{82}$ regarding the language of procedures and the written notifications, and, on the other hand, a personality principle ${ }^{83}$ concerning the language spoken by the citizen in court. The language rules are not to be taken lightly: if they are violated, the proceedings are null and void ex officio ${ }^{84}$ However, a judicial decision after trial corrects the eventual nullity of the preceding judicial instruments. Nevertheless, the annulled instruments will interrupt the period of prescription and the deadlines of proceedings.

In the civil, commercial and labour courts in the French-speaking provinces ${ }^{85}$ or in the French-speaking districts, ${ }^{86}$ the entire procedure takes place in French ${ }^{87}$ The same principle is applied to the Dutch-speaking provinces ${ }^{88}$ and in the Dutch-speaking

\footnotetext{
${ }_{78}$ Sec. 6(1).

79 Sec. 5 provides: 'Language medium at proceedings. - (1) Either of the official languages of the Republic may be used at any stage of the proceedings of a court. (2) If evidence is given in a language with which one of the parties is in the opinion of the court not sufficiently conversant, a competent interpreter may be called by the court to interpret that evidence into a language with which that party appears to be sufficiently conversant, irrespective of whether the language in which the evidence is given is one of the official languages.'

80 See S. Woolman, et al., Constitutional Law of South Africa, 2nd edn. (loose-leaf), (2011, Revision Service 33), at 13-31.

81 Moniteur belge, 22 June 1935. The Supreme court defines a procedural step as 'an act within a process or under the supervision of the court, done by the parties, their representatives or by the assistants of the judge': Cass. 28 April 1988, Arr. Cass. 1987-1988, at 1088.

82 The rule as to the language used in a certain area follows the accepted language limits and does not consider the own language of the person living in that area.

83 The language of every person will be respected, regardless of the residence of that person.

84 Sec. 40 of the 1935 Act.

85 Hainaut, Namur and Luxembourg.

86 Nivelles, Liège, Huy and Verviers.

87 Sec. 1.

88 Antwerp, East Flanders, West Flanders and Limburg.
} 
district ${ }^{89}$ where the entire procedure is conducted in Dutch. ${ }^{90}$ In the courts of the German language district, ${ }^{91}$ all procedures are conducted in German.${ }^{92}$

In the courts of Brussels, proceedings are initiated in French when the defendant resides in the French-speaking part of the country, in Dutch when the defendant resides in the Dutch-speaking area, and in French or Dutch (at the plaintiff's choice) if the defendant resides in the Brussels-agglomeration or when he or she has no known residence in Belgium. ${ }^{93}$ However, when the proceedings are brought in Brussels on the basis of a jurisdictional link to one of the Dutch-speaking areas that fall within the judicial district of Brussels, the proceedings will be conducted in Dutch. ${ }^{94}$

Besides the territoriality principle, which is clear from the rules just set out, the point of departure of the language Act is the use of the same language throughout the procedure. An appeal must be lodged in the language of the contested decision. ${ }^{95}$ Arguments in support of the appeal must be in that same language.${ }^{96}$ In the same vein, proceedings before the Supreme Court are conducted in the language of the contested decision. ${ }^{97}$ However, for purposes of the language Act, the opposition by a third party is considered as a new procedure. ${ }^{98}$ The request for interpretation or correction of a sentence is also considered as a new claim. If documents are submitted in a language other than the language of the proceedings, the court, upon request of the party against whom the documents are invoked, may make a reasoned order that the document be translated into the language of the proceedings. ${ }^{99}$

For purposes of making statements to the court, or lodging objections or presenting an address to the court, the party can use the language that he or she prefers. The same rule is applied to the interrogation and for the taking of the oath. When the judge does not understand the language used or when a party does not understand the language of the proceedings, a sworn interpreter will assist. The cost of translation is borne by the State Treasury. ${ }^{100}$ Witnesses are also heard in the language of the proceedings, unless they request the use of another language. When the judge, the police officer who must interrogate the witness, or one of the other parties does not understand that language, a sworn interpreter assists. The cost of translation is borne by the State Treasury. ${ }_{101}$

Thus it is clear that monolingualism is the rule in legal proceedings in Belgium. ${ }^{102}$ The principle of monolingualism is applied absolutely, even when the concerned person understands the foreign language perfectly well. ${ }^{103}$ In the courts of Brussels, it is possible to change the language of the proceedings. ${ }^{104}$ The defendant may ask that the proceedings (initiated in French or Dutch) continue in the other language (Dutch

89 Leuven.

90 Sec. 2.

91 Eupen.

92 Sec. 2 bis.

93 Sec. $4 \S 1$.

94 Sec. 3. This is the so-called extra muros rule.

95 Sec. 24.

96 Cass. 18 October 2004, RW 2005-2006, at 547, RAGB 2005, at 854, Pas. 2004, I, at 1605; Cass. 16 November 2009, C.09.0254.N; Court of Appeal of Ghent, 8 March 2010, 2008/AR/1103; Court of Appeal of Antwerp, 18 April 2007, 2007AR582.

97 Sec. 27 and 27 bis.

98 Cass. 26 November 1999, RW 2000-2001, at 772, JT 2000, at 419, with case note by H. Boulabah and J. Englebert.

99 Sec. 8 of the 1935 Act.

100 Sec. 30 of the 1935 Act.

101 Sec. 32 of the 1935 Act.

102 See. B. Dejemeppe, 'Une langue peut en révéler une autre', Journal des Tribunaux 407 (2009), case note on Cass. 22 May 2009 and the mentioned references; D. Lindemans, 'De eentalige akte in de Gerechtstaalwet', Tijdschrift voor procesrecht en bewijsrecht 322, (2008); D. Lindemans, 'Schipperen tussen taaleigenheid, anderstaligheid en aantasting van eentaligheid', Rechtskundig Weekblad 672, (2009-2010), case note on Cass. 22 May 2009 and the mentioned references; P. Verguts, 'Taal van de procedureakten: Dura lex sed lex', European Transport Law 220, (2004), case note on Court of Appeal of Antwerp, 2 February 2004.

${ }_{103}$ Court of Appeal of Brussels, 29 April 2008, 2007/SF/3.

104 See J. Clement, 'De taalvrijheid in de Grondwet. Ontwaakt de schone slaapster?', in A. Alen and S. Sottiaux (eds.), Taaleisen juridisch getoetst (2009), at 17-32. 
or French).$^{105}$ Defendants living in municipalities belonging to the language frontier districts ${ }^{106}$ can also request the proceedings to be conducted in French. ${ }^{107}$ This request can also be made by defendants domiciled in the Brussels municipalities with linguistic facilities. ${ }^{108}$ This exception should be raised before any other objections. The judge has a discretion when considering this request. The parties may jointly request the change of the language of the proceedings. In such case, the proceedings will continue in the language requested, without consideration by the judge. Depending on its own statutory language, a court can then either continue the proceedings in the other language, or refer them to another court. We, thus, see a big difference between the way in which the language of legal proceedings is regulated in South Africa and Belgium. Ironically, the fact that the matter is regulated in more detail in Belgium, this does not mean more language protection in practice. The problems of the right to a fair trial, referred to in the previous chapter, are equally pertinent in both countries.

\subsection{Language in Criminal Proceedings: The Right of the Accused}

\section{In South Africa, the Magistrates' Courts Act 32 of 1944 provides}

If, in a criminal case, evidence is given in a language with which the accused is not in the opinion of the court sufficiently conversant, a competent interpreter shall be called by the court in order to translate such evidence into a language with which the accused professes or appears to the court to be sufficiently conversant, irrespective of whether the language in which the evidence is given, is one of the official languages or of whether the representative of the accused is conversant with the language used in the evidence or not. ${ }^{109}$

The application of this Act, already used before 1994, when South Africa had only English and Afrikaans as official languages, is not limited to official languages. Any language can fall in the scope of the provision. Therefore, also languages not spoken in South Africa are included, and the accused person has a right to interpretation. However, a distinction should be made between the right of the accused to understand the proceedings (which can be complied with by a duty of interpretation) and the rules on the language in which a trial is conducted.

In the case of Mthethwa v De Bruin NO and Another, ${ }^{110}$ Mr. Mthethwa applied to have the trial conducted in Zulu, but the magistrate refused. On review, the high court held that Section 35(3)(k) of the Constitution does not give an accused the right to have a trial conducted in the language of his choice. He has a right to be tried in a language he understands, or, if that is not practicable, to have the proceedings interpreted in the language. ${ }^{111}$

In a developing country with 11 official languages, the courts have no choice but to take a pragmatic stance. A noteworthy example is found in $S$ v Domoyi ${ }^{112}$ where the magistrate decided that due to a shortage of interpreters the court proceedings would be conducted in isiXhosa, because all parties, including the presiding officer and the prosecutor, were Xhosa speaking. The magistrate believed that any further postponement

105 Sec $4 \S 1$ of the 1935 Act.

106 Moeskroen, Komen and\& Sint-Martens-Voeren.

107 Sec. 7 § 1 bis.

108 This concerns the following six municipalities, where minorities acquired the right to obtain services in their language of origin: Drogenbos, Kraainem, Linkebeek, Sint-Genesius-Rode, Wemmel, WezembeekOppem, Moeskroen, Komen, Sint-Martens-Voeren; Secs. $4 \S 3$ and 7 bis.

109 Sec. 6(2).

$1101998(1)$ BCRR $336(\mathrm{~N})$.

111 The majority report of the commission of four judges-president appointed to investigate the issue of language use in courts, referred to in more detail below, 44 calls this judgement a low water mark on the question of use and promotion of indigenous languages in South Africa.

1122004 (2) SA 564 (C). 
would compromise the accused's right to a fair trial. On review, the judge confirmed that the proceedings were in accordance with justice. Thus the courts accepted a different language regime, which ensured the right to a fair trial.

In criminal proceedings in Belgium, it is again the principles of territoriality and procedural monolingualism, which dictate the use of language. However, accused persons living in areas close to language borders or in the municipalities close to Brussels that have specific facilities may request the criminal proceedings to be conducted in another language. ${ }^{113}$ If the accused person knows only Dutch, French or German or if he or she expresses him or herself more easily in one of these languages, and when the criminal trial is conducted in another language, the accused person can request the use of Dutch, French or German in the proceedings. ${ }^{114}$

The rules as to the use of language in official documents on the detection and determination of crimes are also related to the particular language area. In Brussels, such documents must be in French or in Dutch according to the language used in the declarations of the person involved; without those declarations, the language will be chosen according to the requirements of the case. ${ }^{115}$ Staff members of the public prosecutor and the investigating judge use, for their acts of prosecution and investigation, the prescribed language in criminal cases before the court.

The accused person who only understands Dutch, French or German may request a translation of the official reports, the statements of witnesses or complainants and the reports of experts into that language. The Treasury bears the cost of that translation. ${ }^{116}$ Throughout all interrogations during the investigation and before court, parties who appear in person use the language of their choice. When the police officers, the prosecutor, the investigating judge or the judges do not know the language used by the parties, they call upon the services of a sworn interpreter. If a party does not understand the language of the proceedings, he or she will be assisted by a sworn interpreter. The State Treasury bears the cost of translation. ${ }^{117}$

The Royal Decree of 16 December 2011 provides that a letter of rights is transmitted before the first interrogation. The right to 'assistance by an interpreter' during the hearing is set out as follows:

If you wish to express yourself in another language than the language of procedure, the police calls on a sworn interpreter to assist you during the questioning. This is free.

(1) If the interviewer knows your language, he can record your statements in your language.

(2) You may be asked to write your statement in your own language.

We, thus, see the reduced value of the status of a language as official language in criminal proceedings. Much rather it is the right to a fair trial that underlies the language protection offered to accused persons.

\subsection{Languages Used in the Constitutional Courts}

Constitutional courts, due to their particular status, have particular language rules, which deserve separate mention. In South Africa, unlike the other statutes discussed above, the Constitutional Court rules allow the use of any official language. Where the record or another document is in a language not understood by all the judges, this must be translated by a sworn translator to a language or languages understood by the judges. The parties must receive a copy of the translation. ${ }^{18}$ It is interesting to note here that the fairness of the trial requires the judge to understand the documents. Such

113 Secs. 14,15 and 16 of the 1935 Act.

114 Sec. 23 of the 1935 Act.

115 Sec. 11 of the 1935 Act.

116 Sec. 22 of the 1935 Act.

117 Sec. 31 of the 1935 Act.

118 Rule 25 of the South African Constitutional Court Rules. 
situation arises in a country with 11 official languages. Of course not all the country's judges can understand all 11 languages. This situation is different from Belgium, which has only three official languages, and where fluency in at least Dutch and French is a criterion in the appointment of judges. The rules of the South African Constitutional Court, furthermore, provide that argument may be addressed to the court in any official language. The party is not responsible for the provision of an interpreter. ${ }^{119}$

The use of languages before the Belgian Constitutional Court is prescribed in the Special Act of 6 January 1989 on the Constitutional Court, which provides that cases shall be instituted before the Constitutional Court in Dutch, French or German. ${ }^{120}$ The Act contains various strict obligations for State officials (of the federal and regional governments) about the languages they must use, again with the sanction of nullity of the proceedings for infringement. Judgements must be pronounced by the presidents in Dutch and in French. They must also be pronounced and published in German in the case of rulings on actions for annulment or if the case was brought before the Court in German. We see again very different rules, against different cultural and historical backgrounds. Yet the rules of both countries aim at language protection, be it in totally different ways.

\subsection{Summons and Notification}

In Belgium, the judicial decisions and documents dealing with enforcement or execution of the judgement are prepared in the language in which the proceedings were conducted. If service of documents must be affected in another language area, a translation should be added. ${ }^{121}$ Strangely, this rule on translation is not applicable to the appeal in cassation (which is the appeal to the highest instance on a point of law). All German documents served in the bilingual area of Brussels must be accompanied by a translation in Dutch and in French. In our view, this rule is not in line with the principle of procedural economy.

In South Africa, the practice is that summonses and other process are issued in English or Afrikaans. The case Cape Killarney Property Investments (Pty) Ltd v. Mahamba and Others ${ }^{122}$ concerned eviction. Judge-President of the Cape High Court Hlope held that the notice served to evict the respondents could only be effective if it was accompanied by a Xhosa translation. ${ }^{123}$ Here, the rights of those against whom service was given were protected in a pragmatic way. The Court's concern was whether there was effective notice to those involved. Here the language protection in South Africa takes the addressee of the notice or service as point of departure. This is in principle also the case in Belgium, although the formalistic notion of territoriality is again paramount.

\subsection{Interpretation}

An accused may come from a cultural background making him or her unfamiliar with the court process. Hlope says that the western court is an alien institution in African culture. ${ }^{124}$ Dlamini says that the adversary system used in the west, coupled with

\footnotetext{
119 Rule 13(4) of the South African Constitutional Court Rules.

120 Sec. 62 of the 1989 Act.

121 Sec. 38 of the 1935 Act.

1222000 (2) SA 67 (C).

123 Par [18], see also J.M. Hlope, 'Official Languages and the Courts', 117 South African Law Journal 690, at $693(2000)$.

124 'Receiving Justice in your own language - the need for effective court interpreting in our multilingual society', Advocate (2004) 42-47, at 45.
} 
restricted rules on admissibility of evidence, is diametrically opposed to the indigenous system of law in South Africa, which inclines towards an inquisitorial approach with a free system of evidence. ${ }^{125}$

When a witness testifies in an indigenous African language, that evidence is interpreted into English or Afrikaans, depending on the whim of the interpreter or the instruction of the presiding office. The interpreted version then becomes the official record. An interpreter is a species of expert witness who tells the court in a language understood by the court what the witness is saying. What the interpreter tells the court becomes the evidence. ${ }^{126}$ Court interpreting is not merely a matter of translating words. The interpreter conveys the evidence given by the witness to the court. The interpretation should convey the total message, with the necessary tone in which it was conveyed. ${ }^{127}$ Regarding Evidence, the Uniform rules of the Superior Court Practice state:

\section{Interpretation of Evidence}

1) Where evidence in any proceedings is given in any language with which the court or a party or his representative is not sufficiently conversant, such evidence shall be interpreted by a competent interpreter, sworn to interpret faithfully and to the best of his ability in the languages concerned.

2) Before any person is employed as an interpreter the court may, if in its opinion it is expedient to do so, or if any party on reasonable grounds so desires, satisfy itself as to the competence and integrity of such person after hearing evidence or otherwise.

3) Where the services of an interpreter are employed in any proceedings, the costs (if any) of interpretation shall, unless the court otherwise orders, be costs in the cause: Provided that where the interpretation of evidence given in one of the official languages of the Republic is required by the representative of a party, such costs shall be at such party's expense. ${ }^{128}$

South Africa has diverse languages, dialects, practices, traditions, cultures and customs. These factors complicate court interpreting. A further complicating factor, which the interpreter must contend with, is that the lah that is interpreted originated from Roman and Roman-Dutch law, influenced by English law. The common law of South Africa is Roman-Dutch law influenced by English law. ${ }^{129}$ Parts of South African law have been codified by statutes. Examples are Companies Law, and, for present purposes, the Criminal Procedure Act 51 of 1977 and the Supreme Court Act 59 of 1959 are the most notable.

As Mahlangu ${ }^{130}$ points out, a language is built on the practices, culture and customs of the people. The court interpreter has to know and understand the culture in which the message is given by the witness in order to convey the idea intended precisely. ${ }^{131}$ The interpreter is a culture broker, who must translate not only words but also ideas, laws and customs. ${ }^{132}$ Interpreters are part of the staff establishment at every court. Whenever a criminal court sits, there will be an interpreter. If the parties to a civil suit require the services of an interpreter for a witness, they arrange that themselves. Usually they enter into an agreement with a court interpreter in the employ of the state who is not at that time required in a criminal court to interpret in the civil case.

Former Chief Justice Langa started his career as an interpreter. Interpreters over the years gain an in-depth knowledge of the working of the justice system. They are able

C.R.M. Dlamini, 'The influence of race on the Administrative of Justice in South Africa', 4 South African Journal on Human Rights 38, (1988).

126 Sv Naidoo 1962 (2) SA 625 (A), at 632H

127 A. Mahlangu, 'From the mouth of a court Interpreter with 45 years experience', <www.justice.gov.za/ juscol/news/200811_MAHLANGU_INTERPRETING.pdf> (27 August 2012). A. Mahlangu is Head of Court Interpreting at Court Interpreting Training at Justice College.

128 H.J. Erasmus, Superior Court Practice, Uniform Rules, Rule 61.

129 Hahlo \& Kahn, above n. 9, at 40.

130 Id.

131 Id.

132 Hlope, Advocate 46. 
to explain the proceedings to accused persons and witnesses, who are in many cases ignorant. ${ }^{133}$ The interpreters are conversant with court proceedings, and the interpreter swears in a witness whose evidence is going to be interpreted. ${ }^{134}$

An interpreter must translate accurately, comprehensively, and without bias. ${ }^{135}$ It is of paramount importance that the interpreter should understand, and be able to properly interpret the evidence given in a language different to the court language. It is the duty of the presiding officer to be alive to signs indicating a lack of proper communication between the witness and the interpreter, especially in the case of an ad hoc interpreter translating the evidence of a witness testifying in a foreign language, for example Thai, to English. Where the record indicates that proper interpretation did not take place, the proceedings will be set aside on review. ${ }^{136}$ It is desirable that all communications in court should be recorded, whereas at present the practice is that only what is said in one of two official languages is recorded. ${ }^{137}$

There are approximately 2,000 interpreters in the full-time employ of the state who work at the various courts. Each interpreter must know at least three languages, including the languages spoken in the area of the court. At a meeting of the Advocates for Transformation held in Mthatha during the weekend of 22 June 2012, retired Judge Poswa expressed the view that many court interpreters are incompetent and that their failure to interpret properly had left thousands of innocent people languishing in prisons. ${ }^{138}$ With this statement, an influential judge emphasised the importance of correct interpretation for the adequate protection of rights. His words reaffirm the idea that a language right can be a vital element of the right to a fair trial.

\section{Language for Official Purposes}

\subsection{Keeping Records of Legal Proceedings}

The doctrine of stare decisis, which applies in South Africa, determines that lower courts are bound by decisions given in higher courts. (All courts must follow decisions of the Constitutional Court, all high courts and lower courts are bound by decisions of the Supreme Court of Appeal, and all lower courts in the area of a high court must follow its decisions) Obviously courts must be able to understand decisions binding upon them, and this means in practice that all decisions of superior courts should be available in English. This rule of stare decisis places a unique requirement on the languages used in court: it is no longer only the rights of the defendant (in civil proceedings) or of the accused (in criminal proceedings) that are relevant, but also the subsequent administration of justice. Pragmatism and lack of resources demand judgements that are easily accessible. It would hamper the administration of justice if a subsequent court would have to wait for the translation of the judgement before continuing with its case. Translating everything into all the official languages, as is done by the European Court of Justice, is simply not feasible in a developing country.

A system exists whereby proceedings in matters before lower courts in which the accused was unrepresented, and sentences above a certain level are imposed (usually entailing imprisonment) are sent within 7 days for review by a high court judge. ${ }^{139}$ This is called automatic review.

\footnotetext{
133 Not to say bewildered.

134 Conversation with Mr Benjamin Bennet Mncayi, senior court interpreter at the Free State High Court, Bloemfontein.

135 N.C. Steytler, above n. 53, at 206, with reference to $S$ v Mzo 1980 (1) SA 538 (C), at 539E.

$136 S$ v Sayed and Another, Kwazulu-Natal High Court, not yet reported, Case Number AR101/2011, delivered on 25 June 2012 by Steyn J.

137 Id., at 221.

138 Newspaper report in the Daily Dispatch, also published in the Legalbrief electronic news service on 25 June 2012.

${ }_{139}$ Sec. 302-304 of the Criminal Procedure Act 51 of 1977.
} 
There have been a few instances where, in rural areas, proceedings were conducted in the language spoken in that area by all the parties - the presiding officer, prosecutor and the accused. In $S$ v Matomela, ${ }^{140}$ the proceedings were conducted in isiXhosa, and Tshabalala $\mathrm{J}$ accepted the record in that language for purposes of the automatic review. $S$ v Matomela dealt with an automatic review. ${ }^{141}$ The evidence, judgement and sentence were all in isiXhosa, one of the 11 official languages of South Africa. The judge asked the magistrate why the Xhosa language was used. The magistrate responded that there was a shortage of interpreters, and all the parties were Xhosa speaking including the presiding officer. The High Court accepted that the proceedings were conducted in accordance with justice. Matomela provided the court with a golden opportunity to advance the use of an indigenous language, but the court's attitude did not advance the use of an African language. ${ }^{142}$

In Belgium, in line with the principle of monolingualism, the record of the proceedings must be in the language in which the proceedings were conducted. The case law has refined the exact meaning of the principle of monolingualism in this regard. First, nonessential remarks such as explanations or illustrations may be in another language. ${ }^{143}$ Second, remarks may be in another language if they are explained in or translated into the language of the proceedings. ${ }^{144}$ Third, words or expressions in another language are accepted if those belong to normal usage or to the language of business, such as the English expressions 'no cure no pay' 'field worker' 'plumbing manager' 'extremely upgraded', or 'WC madame' ${ }^{145}$; if the expression is included in commonly used dictionaries, such ad 'quod non'146 'lucrum cessans' 'damnum emergens' and 'expressis verbis ${ }^{147}$; if it is a commonly known and accepted expression such as 'nul ne plaide par procureur' 148 or 'accessorium sequitur principale' 149 or 'lucrum cessans' and 'damnum emergens ${ }^{150}$ or 'exceptio non adimpleti contractus' and 'pacta sunt servanda' ${ }^{151}$; if the expression is understood in its context, such as the English expression 'stand alone'. ${ }^{152}$ The fact that the average litigant does not understand those terms, has nothing to do with the language law but with the intelligibility of legal terminology. ${ }^{153}$

Fourth, a judgement may also mention the plaintiff's address in French in its considerations after it has been mentioned in Dutch. ${ }^{154}$ An address in the Frenchlanguage area may be used in French, even if the proceedings are in Dutch (and vice versa). ${ }^{155}$ An address may also be mentioned in both the language of that area and in the language of the proceedings. ${ }^{156}$ When names or addresses have no legal translation, there is no violation of the principle of monolingualism. ${ }^{157}$

\footnotetext{
1401998 (3) BCLR 339 (Ck).

141 In terms of the South African Criminal Procedure Act judgements of certain lower courts in which sentences of imprisonment imposed by magistrates on persons who were not legally represented at their trial are as a matter of course sent for scrutiny by a Judge of the High Court.

142 Malan, above n. 59, at 705.

143 Cass. 20 November 2003, Pas. 2003 I, at 1861 and Cass. 17 June 2010, C.09.0494.N.

144 Cass. 2 April 2003, Journal des Tribunaux 630 (2003); Court of Appeal of Brussels, 29 April 2008, 2007/SF/3.

145 Cass. 20 December 2004, Rechtskundig Weekblad 556, (2005-2006).

146 Cass. 19 September 2006, P \& B 2008, at 335, Pas. 2006, I, at 1797 and Rechtspraak Antwerpen Brussel Gent 267, (2007).

147 Court of Appeal of Ghent, 27 May 2009, 2007/AR/2896.

148 Cass. 22 May 2009, Rechtskundig Weekblad 671, (2009-2010) and Journal des Tribunaux 407, (2009).

149 Cass. 16 March 2007, Pas. 2007, I, at 549 and Tijdschrift voor procesrecht en bewijsrecht 23, (2008).

150 Court of Appeal of Ghent 27 May 2009, 2007/AR/2896.

151 Court of Appeal of Antwerp 18 April 2007, 2007AR582

152 Cass. 20th February 2009, Revue de Droit Commerciale Belge 233, (2010); with case note by K. Wagner, 'De sanctieregeling in de taalwet van 1935: Quousque tandem abutere patientia nostra?', at 238.

153 Court of Appeal of Ghent 27 May 2009, 2007/AR/2896.

154 Cass. 24 May 1993, Rechtskundig Weekblad 443, (1993-1994).

155 Cass. 9 June 2006, Pas. 2006, I, at 1377 and Rechtskundig Weekblad 1245, (2007-2008); Cass. 7 June

2007, Pas. 2007, I, at 1177 and Rechtspraak Antwerpen Brussel Gent 1170, (2007).

156 Cass. 19 January 2010, P.09.1340.N.

157 Cass. 14 November 1996, Rechtskundig Weekblad 225, (1997-1998).
} 


\subsection{Language in Which Legislation Is Published}

In South Africa, statutes are generally published in two of the official languages, mostly in English and Afrikaans. Some statues are only published in English, and in a few cases, the other text is in an indigenous language. Before 1994, when South Africa had only two official languages, all legislation was published in both of these languages. The authoritative version was the one signed by the State President, which was in turn Afrikaans or English. This rule no longer exists, and various tools of legislative interpretation are used. The 1996 Constitution explicitly provides that in the event of an inconsistency between the (11) different texts of the Constitution, the English text prevails. ${ }^{158}$

In Belgium, the Act of 31 May 1961 on the use of languages in legislative matters, the preparation, publication and entry into force of laws and regulations, provides that legislation is voted, ratified, promulgated and published in Dutch and in French. A Central Office for German translation of the Federal Public Service Home Affairs is responsible for the translation of the laws into the German language. On the proposal of the Central Office and the advice of the Government of the German Community, the Minister of Justice every 3 months complies a list of laws that have to be translated into German (depending on the interest of those laws for the people of the German-speaking area and giving priority to important texts) and for the creation of 'unofficial coordinations' in German, that is, texts incorporating amendments. During this translation activity, the Central Office considers the rules of German legal terminology. The German translation of the law is published in the Belgian Official Gazette within a reasonable time after its publication in Dutch and French.

Draft laws of the government are presented in the Houses in both languages. Proposals of the members of the Houses are submitted in the language chosen by the author and are ultimately translated by the translation agency. The same applies to amendments presented in the course of the discussions. After their promulgation, the laws are included in the Official Gazette, the Dutch text and the French text facing each other. Differences between the Dutch and French texts are resolved according to the intention of the legislator, which will be determined by ordinary interpretation and without a preference for one text over the other. The original text of a Treaty (to which Belgium is a party) will be published in the Belgian Official Journal with a Dutch or French translation. When the original text is not in Dutch or in French, the translation will be published in both languages (Dutch and French).

\section{Possible Changes in Future}

In South Africa, a committee of four judges-president of the High Courts, ${ }^{159}$ was appointed to investigate the use of languages in courts. They brought out majority and minority reports in 2004 . The majority report ${ }^{160}$ recommends:

1) Civil matters in courts of first instance

i) The plaintiff / applicant can institute proceedings in any one of the 11 official languages.

ii) The defendant / respondent can respond in any one of the 11 official languages.

iii) The state makes available interpretation services to a party who has received court process in a language that party does not understand.

iv) Each party notifies the Registrar of the Court of the official language that person intends to use.

158 Sec. 240 of the 1996 Constitution.

159 Referred to as the Heads of Court.

160 By Judges-president R.M.M. Zondo, J.M. Hlope and J.P. Malherbe. 
v) One of the 11 official languages is used as the language of record in each case, decided by the presiding officer.

vi) The hearing or trial can be conducted in any of the official languages. Whatever anyone says in court is recorded in the original language. Where all the parties and the presiding officer speak a particular indigenous language, it is desirable to conduct the proceedings in that language.

vii) The presiding officer delivers judgement in any official language. In the High Court, if the Judgement is given in any language other than English, a translation of the judgement must be available when the judgement is delivered.

2) Civil Appeals

The record can be translated if there is a need.

\section{3) Criminal Trials}

i) The accused and any witness can speak whatever language they feel comfortable in, and it need not be one of the 11 official languages.

ii) Judgement should, where practicable, be given in a language the accused understands, but the judgement must be given in a language in which the presiding officer feels comfortable.

4) Criminal Appeals

i) The accused has the right to have the record translated into a language the accused understands or speaks, at state expense.

ii) Heads of argument must be translated into a language the accused understands.

iii) The State and the accused are entitled to provide Heads of Argument in any official language, and if any presiding officer does not understand that language, a translation must be provided at state expense.

iv) The accused and State are entitled to argue the appeal in their language of choice, and if the other party or presiding officer does not understand that language, the state must provide an interpreter.

v) If the state or defence wants to argue in a language other than English, that party must notify the registrar 30 days before the hearing.

vi) Judgement in the Appeal can be delivered in any official language. If the accused does not understand that language, a translation must be provided at the time of delivery of the judgement.

\section{5) Automatic Reviews}

i) Where the record of a criminal trial, which was conducted in an indigenous language, is allocated to a judge who does not understand that language, an English translation must be provided.

ii) The judgement in an automatic review must preferably be given in the language of the accused.

The minority report, by Kgomo JP, recommends that English be adopted as the only language of record in the Higher Courts. If a party or legal representative wishes to use a language other than English, they should at their own cost provide an interpreter. All 
process of court must be in English. All Judgements in the higher courts are in English. In the lower courts, the status quo, in terms whereof English and Afrikaans are the only two languages used for the record, is to remain for the time being.

To date nothing has come of the Report. The pre-1994 practice continues. On 12 October 2011, the Minister of Arts and Culture gave notice of his intention to introduce the South African Languages Bill 2011 in the National Assembly. ${ }^{161}$ The Bill contains no express reference to Courts of Law. One of the objects of the Bill is to regulate and monitor the use of official languages by the national government, which includes the Department of Justice and Constitutional Development and the office of the Chief Justice. ${ }^{162}$ Within 18 months of the coming into effect of the Act, each Department will have to adopt a language policy regarding its use of official languages for government purposes. ${ }^{163}$

In accordance with Sections 4 and 30 of the Belgian Constitution, which respectively deal with the language areas and the freedom of usage of language, Belgium has three official languages that are not explicitly pronounced: Dutch, French and German. These languages are fixed to their concerned language areas; that situation seems currently irreversibly stuck. The last institutional agreement ${ }^{164}$ does not bring any change. Concerning the language situation, the institutional pact cares mainly about the Brussels mini-language-wars that Brussels Dutch and French speakers (magistrates and others) are fighting. It seems that the future will, to a large extent, be dictated by the European Union. Besides the Directive of 2010 (referred to above), which has to be implemented by the Member States by October 2013, the European Parliament adopted on 13 December 2011 a Proposal for a European Directive on the right to information in criminal proceedings. ${ }^{165} \mathrm{~A}$ 'letter of rights' would ensure fair criminal trials across the European Union. Suspected or accused persons must be promptly informed of their procedural rights in easy-to-understand language. The right to interpretation and translation will form part of the information required before first police interview. Moreover, it has been pointed out that the strict territoriality principle, as prescribed by the 1935 Act, may not survive the true test of the right to a fair trial.

\section{Conclusion}

Since 1925, the practice in South African Courts has been to conduct legal proceedings in English and Afrikaans. In many cases, both languages are used, for instance, one witness might testify in English, the next in Afrikaans. In civil and criminal court cases conducted today, very little, if anything at all, has changed compared with the pre-1994 period. English and Afrikaans are the languages used in civil and criminal litigation. Some questions are put in English and answered in Afrikaans. This does not make for easy reading of the record. English and Afrikaans have, for the greater part of the 20th century, up to the present, been the exclusive languages of record in civil and criminal courts in South Africa. At present, the main debate is about the other nine official languages, which enjoy equal status to English and Afrikaans. The Constitution exhorts the state 9to take practical and positive measures to elevate the status and advance the use of the indigenous languages. In the law courts so far, no meaningful steps have been taken. The Constitutional Court Rules strive towards the ideal situation affording equal rights to all the official languages. The advancement of the previously neglected indigenous languages also appears from the recommendations of the majority report of

\footnotetext{
161 Government Gazette No. 34675, Government Notice 737 of 2011, 12 October 2011.

162 Sec. 1 of the Bill, which refers to Departments listed in Schedule 1 of the Public Service Act (Proclamation 103 of 1994).

163 Sec. 4 of the Bill.

164 Institutioneel akkoord voor de zesde staatshervorming - Een efficiëntere federale staat en een grotere autonomie voor de deelstaten, <www.dekamer.be/kvvcr/pdf_sections/home/NLdirupo.pdf $>$ (last visited 11 Oct. 2011)

${ }_{165}$ See <www.europarl.europa.eu/sides/getDoc.do?pubRef=-//EP//TEXT+TA+P7-TA-2011$0551+0+\mathrm{DOC}+\mathrm{XML}+\mathrm{V} 0 / / \mathrm{EN}>$. The text of the Commission's Proposal is available at $<\mathrm{http} / /$ ec.europa eu/justice/news/intro/doc/com_2010_392_3_en.pdf $>$.
} 
Heads of Court. At this stage, it is unclear what the practical effect of the languages bill will be if and when that legislation comes into force. The view, in practice, seems to be that English should be used as the language of record. Practicality and cost are limiting factors.

Because of the different language areas in Belgium, the principle of territoriality reigns. A second Belgian principle is the extreme belief in procedural monolinguism. Concerning the language of proceedings and the translation of the writ of summons (or other documents that have to be served), non-official languages or dispersed minorities are not taken into account. Belgian 'written' language protection focuses on three official languages, each of them in their own 'language territory box'. ${ }^{166}$ 'Selective incestuous language protection' would be an appropriate description of such language protection. 'Incestuous' because of the fact that the language protection always leads (or better: returns) to an official language. And 'selective' for the reason that there is no superposition of those three languages ${ }^{167}$ and that therefore language protection only serves particular language minority concentrations (the language areas themselves or the municipalities with linguistic facilities) but no other dispersed minorities or individuals. Hlope says, 'it is unfortunate and unacceptable for judges to allow the right to language use to be tempered unduly by considerations of practicality'. ${ }^{168}$

We have examined the question of whether there is indeed such thing as a right to language or whether this should rather be seen as an element of the right to a fair trial (in both civil and criminal proceedings). There is at this stage no clear-cut answer, but the law is developing on this point. We have also indicated how the historical and cultural contexts of a country, as well as practical issues such as costs, influence the status of languages and the possibilities for litigants and accused persons. Although we agree with Hlope, his words rather represent something to strive for than the reality today.

\footnotetext{
166 Moreover, it seems absurd that, only when the party finds him or herself in court, he or she has access to (oral) language protection by virtue of the assistance of an interpreter, even when it concerns non-official languages.

167 See the thoughts of H. de Schutter, 'Let's Brusselize the World!', in A. Grosserier and Y. Vanderborght (eds.), Arguing About Justice - Essays for Philippe Van Parijs (2011), at 199-206.

168 South African Law Journal 696, (2000).
} 